\title{
Effect of Lime Dissolution Rate in Slag on Hot Metal Dephosphorization
}

\author{
Naoki KIKUCHI, ${ }^{1 * *}$ Akitoshi MATSUI) and Yu-ichi UCHIDA ${ }^{21}$ \\ 1) Steel Research Laboratory, JFE Steel Corporation, 1 Kokan-cho, Fukuyama, Hiroshima, 721-8510 Japan. \\ 2) Department of Products Engineering and Environment Management, Faculty of Engineering, Nippon Institute of Technol- \\ ogy, 4-1 Gakuendai, Miyashito-machi, Saitama, 345-8501 Japan.
}

(Received on September 30, 2019; accepted on November 19, 2019; originally published in Tetsu-toHagané, Vol. 105, 2019, No. 6, pp. 610-618)

\begin{abstract}
In order to clarify the effect of the lime $(\mathrm{CaO})$ dissolution rate in slag on hot metal dephosphorization, a $150 \mathrm{~kg}$ scale hot metal dephosphorization experiment was carried out. The rate of decrease of free $\mathrm{CaO}$ and the dephosphorization rate were measured while varying the ratio of $\mathrm{CaO}$ and $\mathrm{SiO}_{2}$, which was defined as basicity.

The dephosphorization rate showed its maximum value at basicity of around 1.0. At basicity higher than 1.0, the dephosphorization rate decreased due to poor dissolution of $\mathrm{CaO}$ in the flux.

A thermodynamic calculation revealed that crystallization of $2 \mathrm{CaO} \cdot \mathrm{SiO}_{2}\left(-3 \mathrm{CaO} \cdot \mathrm{P}_{2} \mathrm{O}_{5}\right)$ in the liquid slag deteriorated $\mathrm{CaO}$ dissolution when basicity was higher than 1.5.

The mass transfer coefficient of $\mathrm{CaO}$ in slag was calculated assuming that the interface between the $\mathrm{CaO}$ and liquid slag is saturated with $\mathrm{CaO}$. High basicity showed a low mass transfer coefficient.

The apparent slag viscosity was calculated in terms of the solid phase and showed a correlation with the $\mathrm{CaO}$ diffusion rate. The $\mathrm{CaO}$ diffusion rate in slag decreased with higher values of not only the liquid slag viscosity, but also the solid-liquid coexistent slag viscosity. These results suggest the existence of an optimum basicity for effective $\mathrm{CaO}$ dissolution.
\end{abstract}

KEY WORDS: hot metal treatment; CaO dissolution rate; basicity; viscosity.

\section{Introduction}

In recent years, demand for lower phosphorus steel products has increased, while iron ore quality has deteriorated (trend toward higher phosphorus ore), increasing the importance of high efficiency hot metal dephosphorization. $\mathrm{CaO}$ efficiency for dephosphorization is important from the viewpoints of reducing both steelmaking slag generation and production costs. Many studies on increasing dephosphorization efficiency have been reported. ${ }^{1-7)}$ Ogasawara et al. reported that $\mathrm{CaO}$ dissolution was enhanced by increasing $\mathrm{FeO}$ generation in the early stage of dephosphorization. ${ }^{1)}$ Tamura et al. reported that $\mathrm{CaO}$ dissolution was enhanced by blasting $\mathrm{CaO}$ powder from the top lance at the hot spot. ${ }^{2)}$ Other reports have also examined issues such as utilization of a lower melting point agent ${ }^{3,4)}$ and hot recycling of converter slag. ${ }^{5)}$ However, basic knowledge concerning the dissolution behavior of $\mathrm{CaO}$ into slag is still insufficient. Matsushima et al. ${ }^{6}$ ) evaluated the $\mathrm{CaO}$ dissolution rate into slag by rotating $\mathrm{CaO}$ processed in a cylindrical shape at 200 to $400 \mathrm{rpm}$ in $\mathrm{FeO}-\mathrm{CaO}-\mathrm{SiO}_{2}$ slag at $1673 \mathrm{~K}$, and evaluated the $\mathrm{CaO}$ dissolution rate by measuring the rate of decrease in the diameter of the cylindrical $\mathrm{CaO}$. However,

\footnotetext{
* Corresponding author: E-mail: n-kikuchi@jfe-steel.co.jp DOI: https://doi.org/10.2355/isijinternational.ISIJINT-2019-622
}

the slag composition was limited to the lower slag basicity $\left((\% \mathrm{CaO}) /\left(\% \mathrm{SiO}_{2}\right)\right)$ region between 0.6 and 1.0 , which does not represent a practical condition in hot metal dephosphorization treatment. Kitamura et $a l^{7)}$ reported the effect of precipitation and dissolution of the solid phase in slag on the dephosphorization rate by an analysis using a coupled reaction model. However, because they assumed the $\mathrm{CaO}$ dissolution rate under the condition of higher slag basicity based on the relationship between the solid phase ratio and the viscosity of the slag, an accurate evaluation of the effect of slag basicity was not possible.

In the present work, $60 \mathrm{~kg}$-scale hot metal dephosphorization experiments were carried out in order to evaluate the effect of the $\mathrm{CaO}$ dissolution rate into slag on hot metal dephosphorization. In these experiments, the melting behavior of the undissolved $\mathrm{CaO}$ in the dephosphorization agent was investigated, and the relationship with the hot metal dephosphorization rate was evaluated. The factors which affect the dissolution behavior of the dephosphorization agent are the chemical composition, size, and amount of the dephosphorization agent, the hot metal temperature, and the stirring condition of the hot metal. However, it was difficult to evaluate the effect of the agent size, as a small-scale melting furnace was used in these experiments. Therefore, a well-ground agent was evaluated at a constant size in this work. Moreover, top-blowing oxygen should be supplied to 
the hot metal to simulate the hot metal dephosphorization process, but in this work, the oxygen was supplied by adding iron oxide powder at fixed intervals to avoid splashing of the hot metal and slag, which cannot be assumed as a constant condition. The effect of the slag composition (basicity) on the $\mathrm{CaO}$ dissolution rate was evaluated under the conditions of a constant hot metal temperature and bottom-blowing gas flow rate. The solubility of $\mathrm{CaO}$ was calculated by Factsage, ${ }^{9,10)}$ and the $\mathrm{CaO}$ dissolution rate was analyzed. In addition, the obtained mass transfer rate constant was compared with those in the other reports.

\section{Experimental Procedure}

Hot metal dephosphorization experiments were carried out with a $150 \mathrm{~kg}$-scale induction furnace $(\varphi 260 \times 500$ $\mathrm{mmH})$. A schematic drawing and the experimental conditions are shown in Fig. 1 and Table 1, respectively. First, $60 \mathrm{~kg}$ of pure iron was melted in a $\mathrm{MgO}$ crucible and adjusted to the predetermined chemistry (3.5 wt $\% \mathrm{C}-0.1$ $\mathrm{wt} \% \mathrm{P})$ and temperature $(1623 \pm 20 \mathrm{~K})$ with a carbon material ("CarboNet", LNS, Asahi Industry Corporation) and $\mathrm{Fe}-\mathrm{P}$ alloy. Burned $\mathrm{CaO}$ (Ube Material Industries, - 0.1 $\mathrm{mm}$ ) and $\mathrm{SiO}_{2}$ (Kishida Chemical) were mixed and used as the dephosphorization agent. The aimed slag basicity, $\mathrm{C} / \mathrm{S}_{\text {aimed }}$, was set by changing proportions of the burned $\mathrm{CaO}$ powder and $\mathrm{SiO}_{2} .18 .7 \mathrm{~kg} / \mathrm{t}$ of the dephosphorization agent was added from the top at the beginning of the experiment. Iron ore powder $\left(\mathrm{Fe}_{\mathrm{t}} \mathrm{O}: 95 \mathrm{wt} \%, \mathrm{SiO}_{2}: 3 \mathrm{wt} \%\right.$, total amount: $50 \mathrm{~kg} / \mathrm{t}$ ) was added from the top between the beginning and

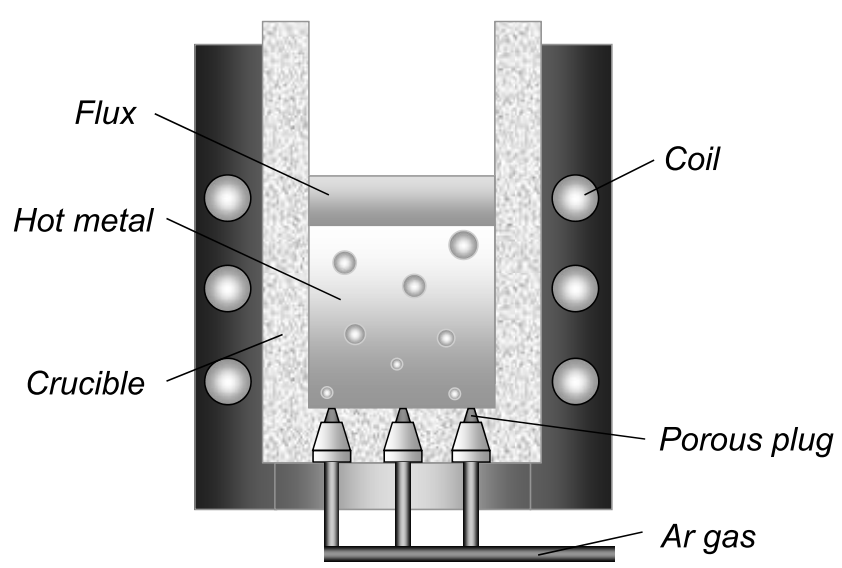

Fig. 1. Schematic illustration of experimental setup.

Table 1. Experimental conditions.

\begin{tabular}{|c|c|c|}
\hline \multicolumn{2}{|c|}{ Furnace } & $150 \mathrm{~kg}$ induction Furnace \\
\hline \multicolumn{2}{|c|}{ Crucible } & $\mathrm{MgO}, \varphi 0.25 \mathrm{~m}$ \\
\hline \multirow{3}{*}{ Metal } & Weight & $60(\mathrm{~kg})$ \\
\hline & Composition & {$[\% \mathrm{C}]=3.5,[\% \mathrm{P}]=0.1$} \\
\hline & Temperature & $1623(\mathrm{~K})$ \\
\hline \multirow{3}{*}{ Flux } & $\mathrm{CaO}+\mathrm{SiO}_{2}$ & $\begin{array}{c}18.7(\mathrm{~kg} / \mathrm{t}) \\
\text { (added at beginning of experiment) }\end{array}$ \\
\hline & $\mathrm{CaO} / \mathrm{SiO}_{2}$ & $0.5,0.75,1.0,1.5,2.0,2.5,3.0,3.5$ \\
\hline & $\mathrm{Fe}_{2} \mathrm{O}_{3}$ & $\begin{array}{c}6.25(\mathrm{~kg} / \mathrm{t}) \times 8 \\
\text { (added at } 5 \mathrm{~min} \text { intervals) }\end{array}$ \\
\hline
\end{tabular}

$35 \mathrm{~min}$ at $5 \mathrm{~min}$ intervals ( 8 times). During the experiments, 25-30 NL/min of Ar gas was supplied from a porous plug at the bottom of the $\mathrm{MgO}$ crucible. Iron ore was not added between 35 and $60 \mathrm{~min}$. Metal and slag samples were taken during the experiment at $5 \mathrm{~min}$ intervals. The metal samples were ground and supplied for wet analysis. The slag samples were cooled in the air, ground, and supplied for wet luminescence analysis. Free $\mathrm{CaO}$ in the slag was sampled by extraction separation with ethylene glycol and analyzed by atomic absorption.

\section{Experimental Results}

\subsection{Dephosphorization Behavior}

Figure 2 shows an example of the change of the phosphorus content $(\mathrm{wt} \%)$ in the hot metal, $[\% \mathrm{P}]$, with time. The dephosphorization reaction proceeded by addition of iron ore, which is an oxygen source. The dephosphorization rate was fast in the order $\mathrm{C} / \mathrm{S}_{\text {aimed }} 1.0,0.5,3.5$ and 2.0 , which does not agree with the thermodynamic order. The change of $[\% \mathrm{P}]$ during 0 to 20 min was regarded as a roughly firstorder reaction. Under higher basicity conditions of more than 2.0, the dephosphorization reaction did not proceed after $25 \mathrm{~min}$, even with iron ore addition.

The relationship between the dephosphorization rate between 0 and $20 \mathrm{~min}$ and $\mathrm{C} / \mathrm{S}_{\text {aimed }}$ is shown in Fig. 3. The dephosphorization rate was defined by Eq. (1), and was also calculated for other conditions not shown in Fig. 2.

$$
\frac{d[\% \mathrm{P}]}{d t}=\frac{[\% \mathrm{P}]_{20 \min }-[\% \mathrm{P}]_{\text {initial }}}{20}
$$

Here, $[\% \mathrm{P}]_{20 \min }$ is the weight percent of the phosphorus content in the hot metal at $20 \mathrm{~min},[\% \mathrm{P}]_{\text {initial }}$ is the weight percent of the phosphorus content in the hot metal at the beginning of the experiment, and $t$ is time (min).

As shown in Fig. 3, the dephosphorization rate increased with increasing $\mathrm{C} / \mathrm{S}_{\text {aimed }}$ in the range of $\mathrm{C} / \mathrm{S}_{\text {aimed }}$ between 0.5 and 1.0. The maximum dephosphorization rate was obtained when $\mathrm{C} / \mathrm{S}_{\text {aimed }}$ was 1.0 , and the dephosphorization rate decreased at higher $\mathrm{C} / \mathrm{S}_{\text {aimed }}$ of more than 1.5 . It is considered that the dephophorization rates at the lower $\mathrm{C} / \mathrm{S}_{\text {aimed }}$ of 0.5 and 0.75 were low due to a shortage of $\mathrm{CaO}$. On the

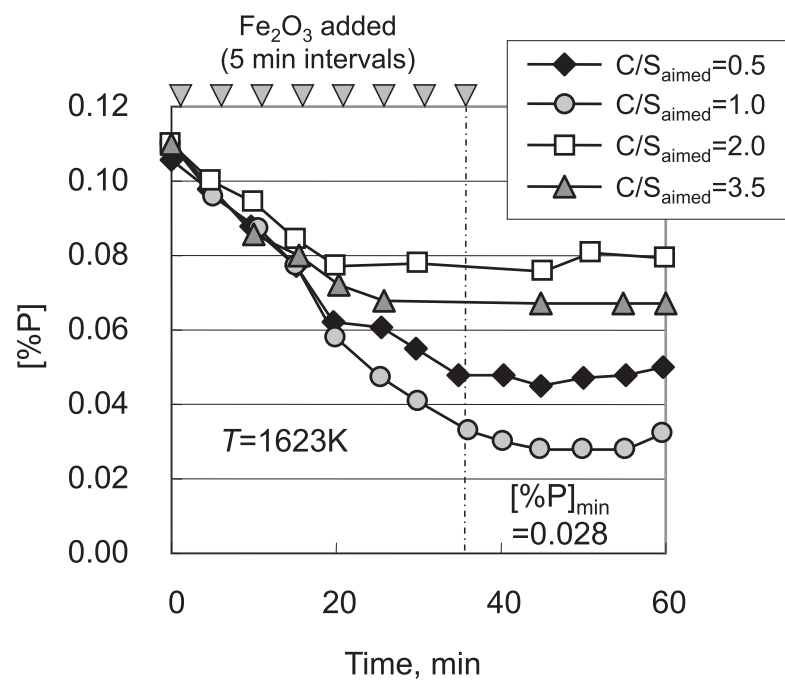

Fig. 2. Changes in $[\% \mathrm{P}]$ with time. 


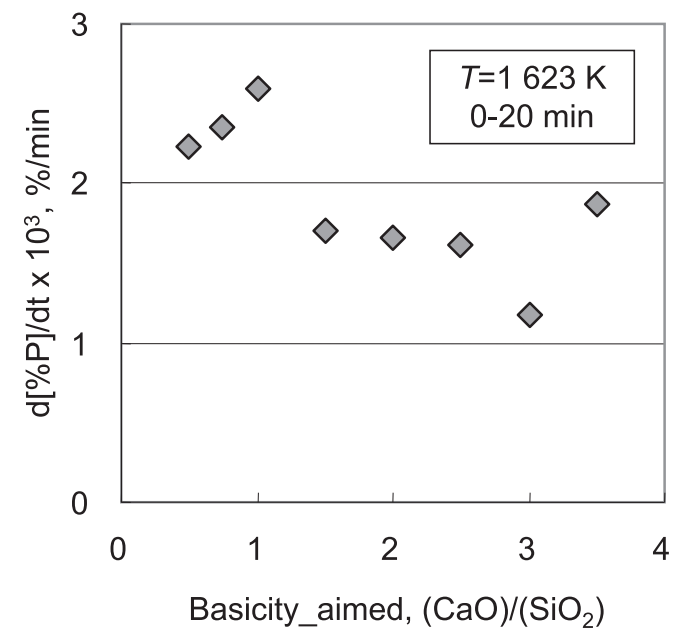

Fig. 3. Dephosphorization rate calculated at each aimed basicity.

other hand, solidified slag was observed under high $\mathrm{C} / \mathrm{S}_{\text {aimed }}$ conditions between 1.5 and 3.5. Under those conditions, the dephosphorization rates were low because the added $\mathrm{CaO}$ did not melt, and thus did not function as a dephosphorization agent.

\subsection{CaO Melting Behavior}

The change in the slag chemistry corresponding to $\mathrm{CaO}$ dissolution is important for evaluating the effect of slag basicity on hot metal dephosphorization behavior. In this work, the transition of undissolved $\mathrm{CaO}$, i.e., free $\mathrm{CaO}$ (hereinafter, $\mathrm{f}-\mathrm{CaO}$ ), is the focus of study for evaluating the $\mathrm{CaO}$ dissolution at each slag basicity. The solid ratio of $\mathrm{CaO}$ is defined as shown in Eq. (2).

$$
\mathrm{CaO} \text { solid ratio }=\frac{(\% \mathrm{f}-\mathrm{CaO})}{(\% \mathrm{CaO})} \times 100
$$

Here, $(\% \mathrm{CaO})$ is the total $\mathrm{CaO}$ content ( $\mathrm{wt} \%)$ including $\mathrm{f}-\mathrm{CaO}$, and $(\% \mathrm{f}-\mathrm{CaO})$ is the free $\mathrm{CaO}$ content $(\mathrm{wt} \%)$ in the slag. The change of the solid $\mathrm{CaO}$ ratio is shown in Fig. 4. The solid $\mathrm{CaO}$ ratio decreased under all conditions of aimed slag basicity. Substantially $100 \%$ of the added $\mathrm{CaO}$ dissolved at lower aimed slag basicities smaller than 1.0, and the remaining $\mathrm{f}-\mathrm{CaO}$ increased as the aimed slag basicity increased.

Figure 5 shows the relationship between the aimed and observed slag basicity. Here, the observed slag basicity was calculated from the dissolved $\mathrm{CaO}$ content by subtracting $(\% \mathrm{f}-\mathrm{CaO})$ from $(\% \mathrm{CaO})$ and $\left(\% \mathrm{SiO}_{2}\right)$, as shown in Eq. (3).

$$
\text { Basicity_obs. }=\frac{(\% \mathrm{CaO})-(\% \mathrm{f}-\mathrm{CaO})}{\left(\% \mathrm{SiO}_{2}\right)}
$$

As shown in Fig. 5, the observed slag basicities approached the aimed value with time, but the difference between the observed and aimed slag basicities expanded as the aimed slag basicity increased. Especially at the aimed slag basicity of $3.5,50 \%$ of the added $\mathrm{CaO}$ did not contribute to the dephosphorization reaction at $10 \mathrm{~min}$. Therefore, the added $\mathrm{CaO}$ did not contribute to dephosprization at $1623 \mathrm{~K}$ due to the lower $\mathrm{CaO}$ dissolution rate.

\subsection{Reduction Behavioir of Iron Oxide}

Figure 6 shows an example of the change of the iron

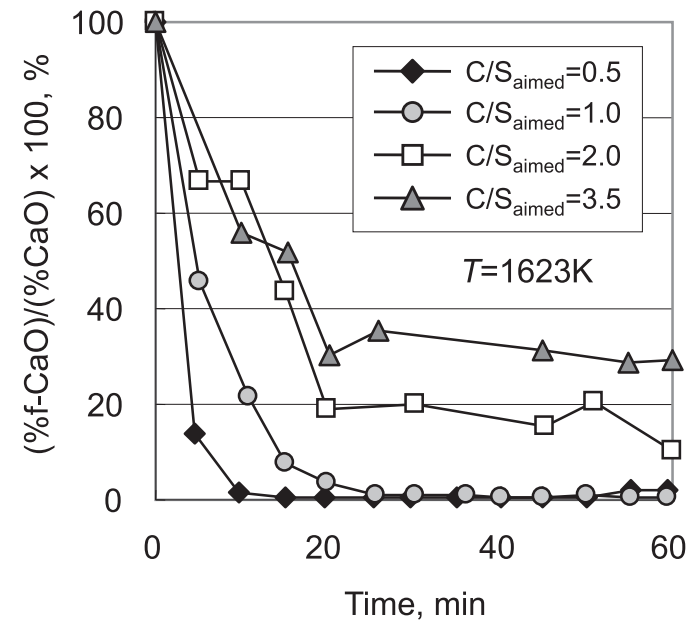

Fig. 4. Influence of aimed basicity on decrease of f-CaO.

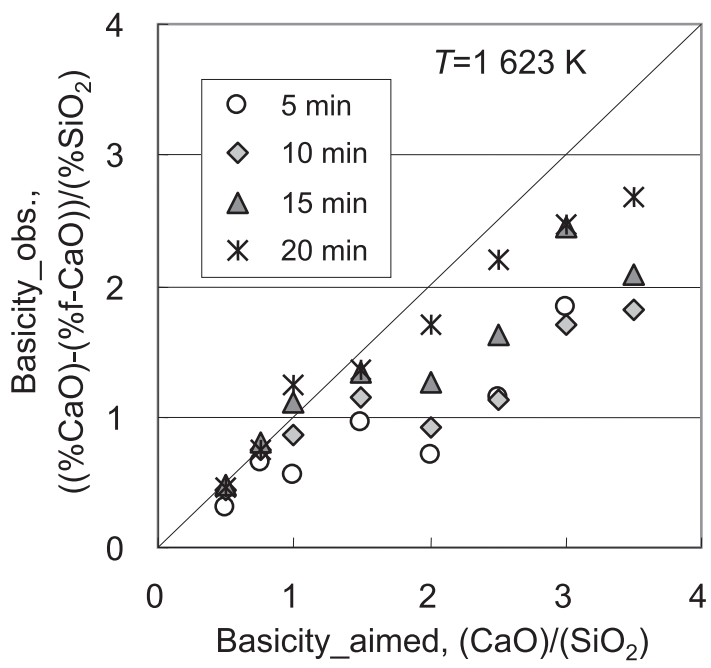

Fig. 5. Comparison between aimed and observed basicity.

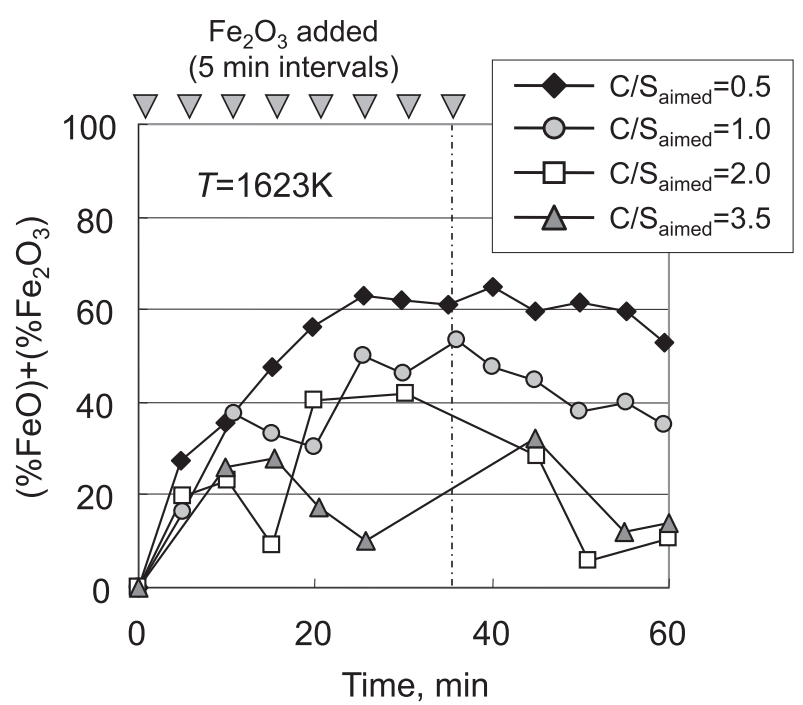

Fig. 6. Changes in $(\% \mathrm{FeO})+\left(\% \mathrm{Fe}_{2} \mathrm{O}_{3}\right)$ with time.

oxide content $\left(\mathrm{wt} \% \mathrm{FeO}+\mathrm{wt} \% \mathrm{Fe}_{2} \mathrm{O}_{3}\right)$ in the slag at each level of $\mathrm{C} / \mathrm{S}_{\text {aimed }}$. The iron oxide content tends to be lower at higher slag basicities. Therefore, the reduction rate of the added iron oxide is considered to be higher at higher slag basicity, since the addition rate of iron oxide is the same 
under all conditions. (The iron oxide mainly reacts with the carbon in the hot metal as an oxygen source). Although it is conceivable that slag foaming or other second-order effects caused by decarburization might affect $\mathrm{CaO}$ dissolution, this point is not considered here due to the complexity of the phenomena. Hence, the $\mathrm{CaO}$ dissolution rate was analyzed by using the obtained iron oxide content in the slag.

\section{Discussion}

\subsection{Procedure for Calculation of $\mathrm{CaO}$ Dissolution Rate}

The relationship between the slag basicity and $\mathrm{CaO}$ dissolution rate was evaluated based on the decreasing rate of the obtained $\mathrm{f}-\mathrm{CaO}$ and the saturated $\mathrm{CaO}$ contant calculated by Factsage. ${ }^{910)}$ Figure 7 shows a conceptional diagram of $\mathrm{CaO}$ dissolution in slag. Solid $\mathrm{CaO}$ exists in the liquid bulk slag. At higher slag basicities, the liquid bulk slag coexists with the dicalcium silcate phase $(2 \mathrm{CS}$, or with tricalcium phosphate $2 \mathrm{CS}(-3 \mathrm{CP})$ ). The interface between the solid $\mathrm{CaO}$ and the liquid bulk slag can be regarded as $\mathrm{CaO}$ saturation during $\mathrm{CaO}$ dissolution.

Matsushima et al. ${ }^{6}$ ) reported that the $\mathrm{CaO}$ dissolution rate is proportional to the difference between the liquid $\mathrm{CaO}$ content $\left((\% \mathrm{CaO})_{\text {liquid }}\right)$ and the saturated $\mathrm{CaO}$ content at the interface of solid $\mathrm{CaO}\left((\% \mathrm{CaO})_{\text {sat. }}\right)$. In their paper, $(\% \mathrm{CaO})_{\text {sat. }}$ was obtained by using the $\mathrm{CaO}-\mathrm{SiO}_{2}-\mathrm{Fe}_{\mathrm{t}} \mathrm{O}$ phase diagram shown in Fig. 8. In Fig. 8, $(\% \mathrm{CaO})_{\text {sat. }}$ can be obtained by finding the intersection bewteen the lines. In Fig. 8, one line is produced by joining the bulk slag composition (Fig. 8(1) and the vertex of $\mathrm{CaO}$, and the other line is the $\mathrm{CaO}$ saturated liquidus line (Fig. 8(2)). In their study, the precipitated solid phase can be ignored since the aimed slag basicities are 0.6 and 1.0. However, in actual hot metal dephosphorization, the solid phase cannot be ignored as the slag basicity is higher than those in their study. Hence, the change of $(\% \mathrm{CaO})_{\text {liquid }}$ is evaluated by expanding their approach as shown in Eq. (4). Here, the driving force of $\mathrm{CaO}$ dissolution $(\Delta(\% \mathrm{CaO}))$ and $(\% \mathrm{CaO})_{\text {liquid }}$ are defined by Eqs. (5) and (6), respectively.

$$
\begin{gathered}
\frac{d(\% \mathrm{CaO})_{\text {liquid }}}{d t}=K_{\mathrm{CaO}}\{\Delta(\% \mathrm{CaO})\} \ldots . \\
\Delta(\% \mathrm{CaO})=(\% \mathrm{CaO})_{\text {sat. }}-(\% \mathrm{CaO})_{\text {liquid }}
\end{gathered}
$$

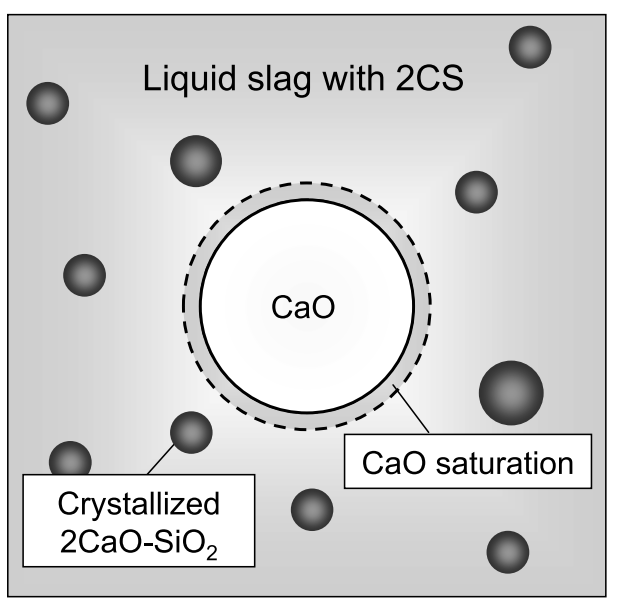

Fig. 7. Schematic illustration of $\mathrm{CaO}$ dissolution.

$$
(\% \mathrm{CaO})_{\text {liquid }}=(\% \mathrm{CaO})-(\% \mathrm{f}-\mathrm{CaO})-(\% \mathrm{CaO})_{2 \mathrm{Cs}-3 \mathrm{CP}} \ldots
$$

Here, $\mathrm{K}_{\text {cao }}$ is the overall reaction rate constant $(1 / \mathrm{min})$ and $(\% \mathrm{CaO})_{2 \mathrm{cs}-3 \mathrm{cp}}$ is the precipitated $\mathrm{CaO}$ content $(\mathrm{wt} \%)$ as $2 \mathrm{CS}$ $3 \mathrm{CP} .(\% \mathrm{CaO})_{\text {sat. }}$ and $(\% \mathrm{CaO})_{2 \text { cs-3cp }}$ are calculated by using the ternary phase diagrams shown in Figs. 8 and 9 based on the procedure in Fig. 10. First, the bulk slag composition is obtained by subtracting $\mathrm{f}-\mathrm{CaO}$ from the slag composition obtained by a chemical analysis, and an equilibrium calculation using the obtained slag composition (1) in Figs. 8 and 9). Here, the bulk liquid $\mathrm{CaO}$ content is assumed to be the bulk slag content in the case without precipitation of the $2 \mathrm{CS}(-3 \mathrm{CP}$ ) phase (1) Fig. 8). On the other hand, in the case with precipiutation of the $2 \mathrm{CS}(-3 \mathrm{CP})$ phase, the bulk slag composition is assumed to be the slag composition coexisting with $2 \mathrm{CS}-3 \mathrm{CP}$. Next, an equilibrium calculation based on the obtained liquid slag composition is conducted by increasing the $\mathrm{CaO}$ content while keeping the same weight ratio of the other components except for $\mathrm{CaO}$. The calculation is repeated until $\mathrm{CaO}$ precipitation occurs, and the obtained slag composition is assumed as $(\% \mathrm{CaO})_{\text {sat. }}$ (2) in Figs. 8 and 9$)$.

\subsection{Calculation Results of $(\% \mathrm{CaO})$ sat.}

The relationship between the observed slag basicity and $(\% \mathrm{CaO})_{\text {sat. }}$ is shown in Fig. 11. $(\% \mathrm{CaO})$ sat. is obtained by an equilibrium calculation in a $\mathrm{CaO}-\mathrm{SiO}_{2}-\mathrm{FeO}-\mathrm{Fe}_{2} \mathrm{O}_{3}-$ $\mathrm{Al}_{2} \mathrm{O}_{3}-\mathrm{P}_{2} \mathrm{O}_{5}-\mathrm{MgO}-\mathrm{MnO}$ system considering 2CS(-3CP)

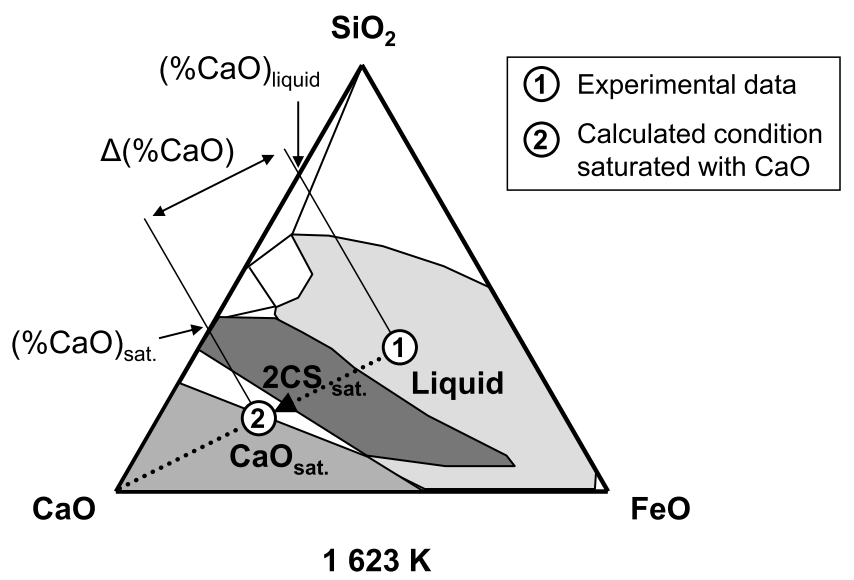

Fig. 8. Calculation of $(\% \mathrm{CaO})_{\text {sat. }}$ without $2 \mathrm{CS}$ crystallization.

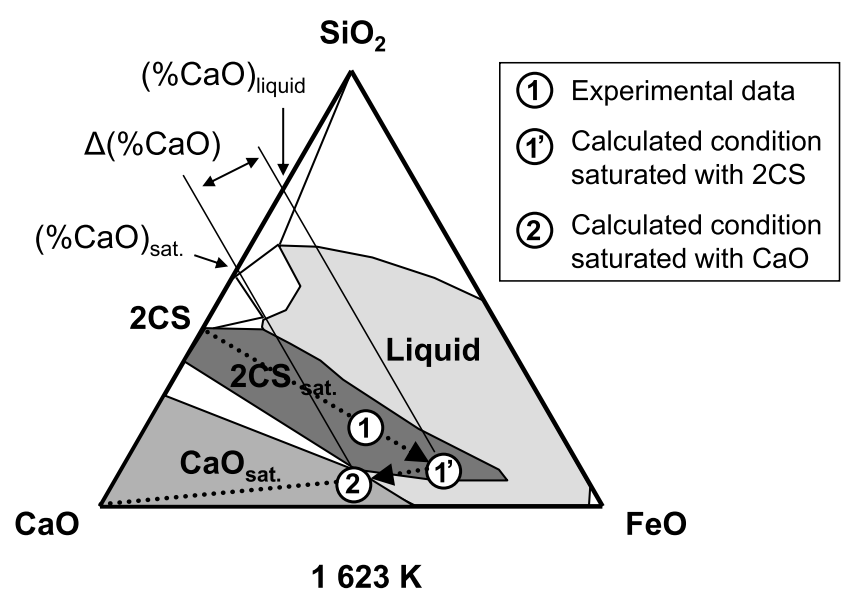

Fig. 9. Calculation of $(\% \mathrm{CaO})_{\text {sat }}$ with $2 \mathrm{CS}$ crystallization. 


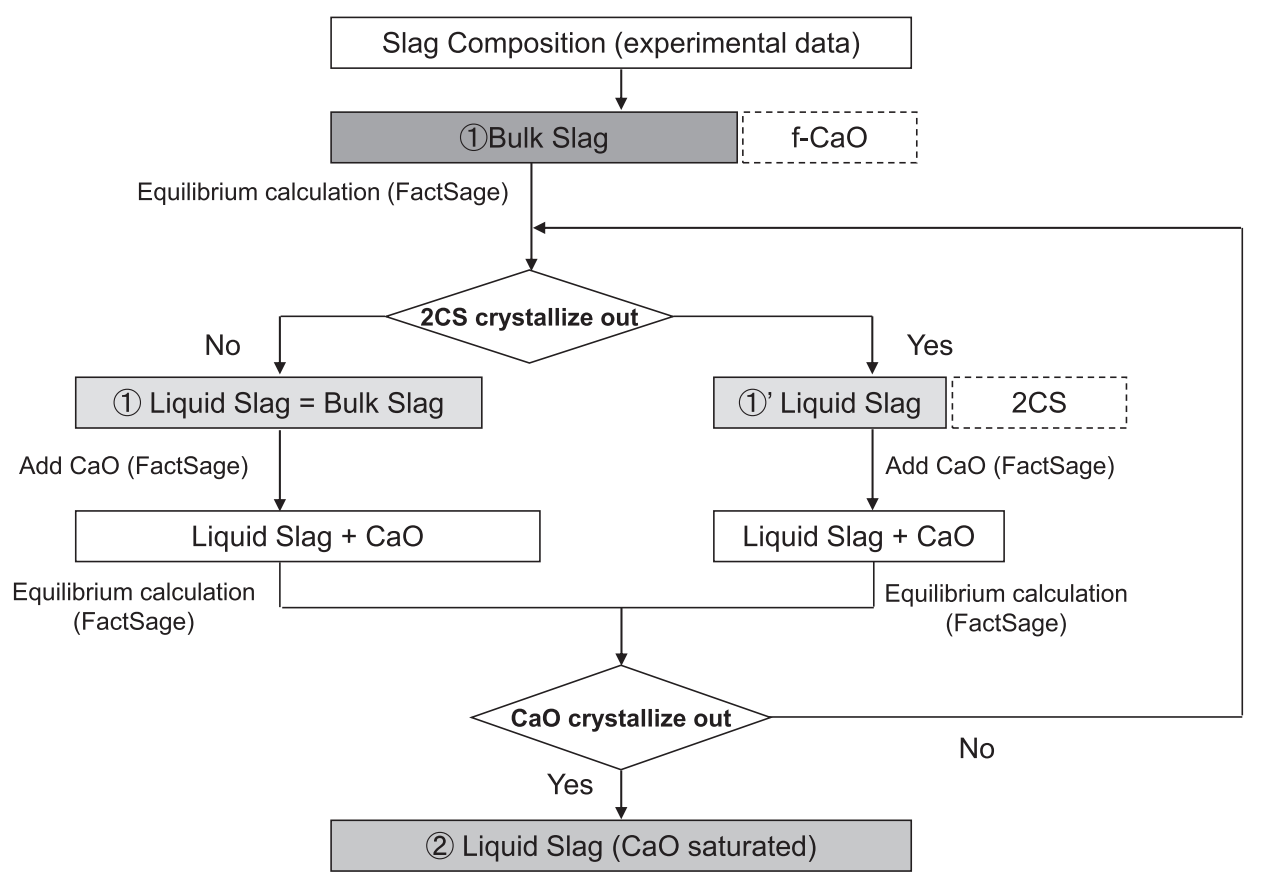

Fig. 10. Procedure for calculation of liquid and $\mathrm{CaO}$ saturated slag composition.

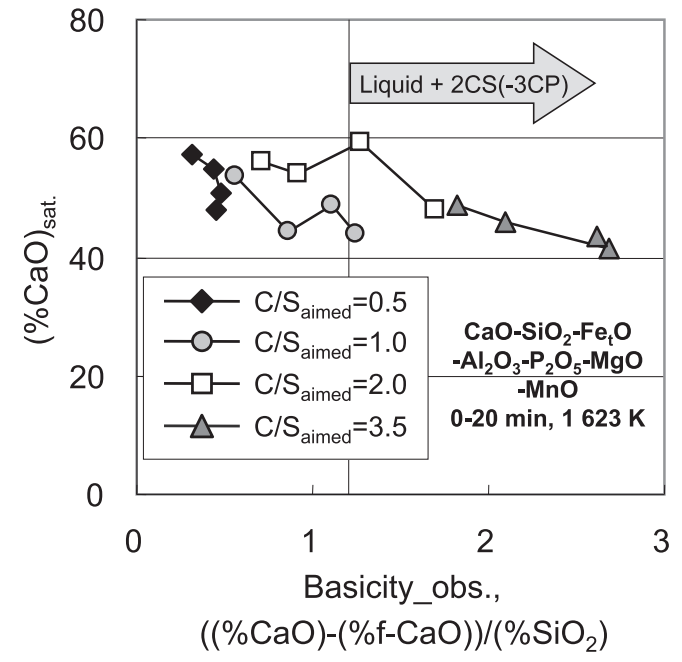

Fig. 11. Variation of $(\% \mathrm{CaO})_{\text {sat. }}$ with observed basicity.

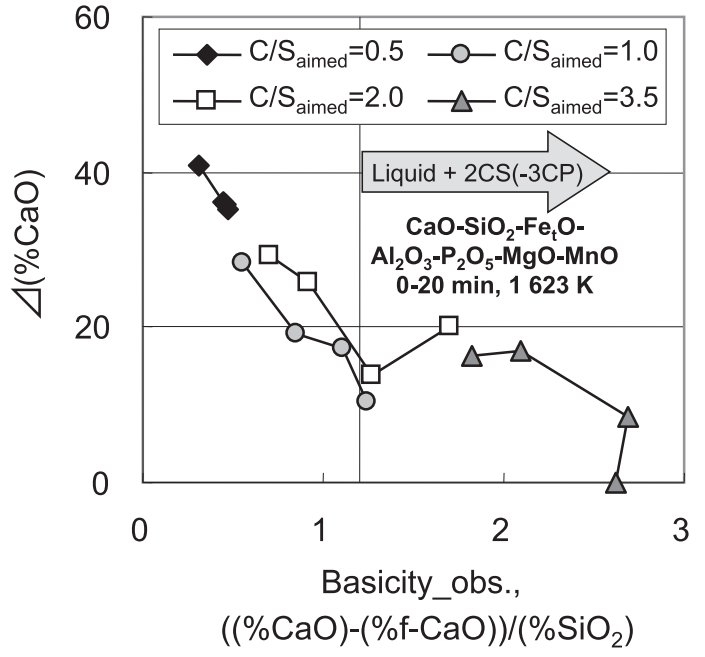

Fig. 12. Variation of $\Delta(\% \mathrm{CaO})$ with observed basicity. precipitation. The observed slag basicity is calculated by Eq. (3). In Fig. 11, the observed slag basicity changes from lower to higher slag basicity as $\mathrm{CaO}$ dissolution progresses with time. The $2 \mathrm{CS}(-3 \mathrm{CP})$ phase precipitates under the condition that the observed slag basicity is higher than 1.2. The obtained $(\% \mathrm{CaO})_{\text {sat. }}$ is in the range between 40 and $60 \%$. $(\% \mathrm{CaO})_{\text {sat. }}$ of the liquid slag tends to be lower with higher observed slag basicity. Moreover, the values of $(\% \mathrm{CaO})_{\text {sat. }}$ at lower aimed slag basicities between 0.5 and 1.0 are higher than those at higher aimed slag basicities of 2.0 to 3.5. This is caused by the change in the liquid slag composition as the reduction rate of the added iron ore changes. The relationship between the observed slag basicity and $\Delta(\% \mathrm{CaO})$ is shown in Fig. 12. Here, $\Delta(\% \mathrm{CaO})$ is calculated by Eq. (5). $\Delta(\% \mathrm{CaO})$ tends to decrease as the observed slag basicity increases, but stagnates due to $2 \mathrm{CS}(-3 \mathrm{CP})$ precipitation. This is caused by the difference between the liquidus lines at the higher and the lower $\mathrm{CaO}$ side of the 2CS saturation region, as shown in Fig. 9.

\subsection{Calculation of Overall Reaction Rate Constant $\left(\mathbf{K}_{\text {cao }}\right)$}

Equation (7) is obtained by integrating both sides of Eq. (4).

$$
\ln \frac{(\% \mathrm{CaO})_{\text {sat. }}}{(\% \mathrm{CaO})_{\text {sat. }}-(\% \mathrm{CaO})_{\text {liquid }}}=K_{\mathrm{CaO}} \times t
$$

The $\mathrm{CaO}$ dissolution rate is organized by the calculated $\mathrm{CaO}$ saturation solubility. The result is shown in Fig. 13. In Fig. 13, the plots at $5 \mathrm{~min}$ are higher than the other plots after $5 \mathrm{~min}$. It is thought that the added $\mathrm{CaO}$ at $5 \mathrm{~min}$ is easily dissolved in $\mathrm{SiO}_{2}-\mathrm{Fe}_{\mathrm{t}} \mathrm{O}$ slag, which is a dilute $\mathrm{CaO}$ solution. Hence, the analysis was carried out on the assumption that the $\mathrm{CaO}$ dissolution rate can be organized by the first-order reaction from 0 to $20 \mathrm{~min}$ if the data at $5 \mathrm{~min}$ are excluded. The lines in Fig. 13 are obtained by approximation by the least-squares method for the case in which the y-intercept is 0 . The slope of the lines is equivalent to the overall reaction rate constant $\left(\mathrm{K}_{\text {cao }}\right)$. $\mathrm{K}_{\text {cao }}$ for the other conditions was 


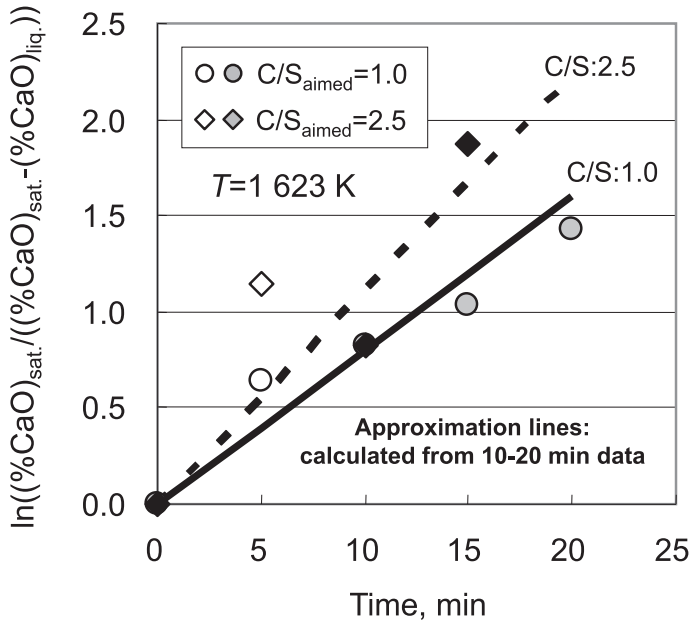

Fig. 13. Relationship between time and value of left side of Eq. (7).

also organized and calculated in the same way as in Fig. 13.

The mass transfer rate of $\mathrm{CaO}$ is discussed in order to understand the physical meaning of $\mathrm{K}_{\mathrm{cao}}$. The relationship between $\mathrm{K}_{\mathrm{cao}}$ and the mass transfer rate is defined as show in Eq. (8). Here, $V_{\text {bulk slag }}\left(\mathrm{m}^{3}\right)$ is the total slag volume combining the solid and liquid volumes, and $\mathrm{A}_{\mathrm{f}-\mathrm{cao}}\left(\mathrm{m}^{2}\right)$ is the sum of the surface area of $\mathrm{f}-\mathrm{CaO}$. The mass transfer rate of $\mathrm{CaO}$ in the liquid slag, $\mathrm{k}_{\text {cao }}(\mathrm{cm} / \mathrm{s})$, can be ontained by Eq. (9), which is obtained by deforming Eq. (8).

$$
\begin{gathered}
K_{\mathrm{CaO}} \times \frac{1}{60}=-\frac{A_{\mathrm{f}-\mathrm{CaO}}}{V_{\text {bulk_slag }}} \times \frac{1}{100} \times k_{\mathrm{CaO}} \\
k_{\mathrm{CaO}}=K_{\mathrm{CaO}} \times \frac{100}{60} \times \frac{V_{\text {bulk_slag }}}{A_{\mathrm{f}-\mathrm{CaO}}} \ldots . . .
\end{gathered}
$$

Here, the undissolved $\mathrm{CaO}$ is defined as a sphere of uniform size, and the slag volume, $\mathrm{V}_{\text {bulk slah }}\left(\mathrm{m}^{3}\right)$, and the sum of the surface area of $\mathrm{f}-\mathrm{CaO}, \mathrm{A}_{\mathrm{f}-\mathrm{cao}}\left(\mathrm{m}^{2}\right)$, are calculated by Eqs. (10) and (15), respectively.

$$
\begin{aligned}
& V_{\text {bulk_slag }}=\frac{W_{\mathrm{s}}}{\rho_{\mathrm{s}}} \\
& W_{\mathrm{s}}=\mathrm{CaO}(\mathrm{kg} / \mathrm{kg}) \times W_{\mathrm{m}} \times \frac{100}{(\% \mathrm{CaO})} \\
& V_{\mathrm{f}-\mathrm{CaO}}=\frac{W_{\mathrm{f}-\mathrm{CaO}}}{\rho_{\mathrm{f}-\mathrm{CaO}}} \\
& W_{\mathrm{f}-\mathrm{CaO}}=W_{\mathrm{s}} \times \frac{(\% \mathrm{f}-\mathrm{CaO})}{100} \\
& V_{\mathrm{f}-\mathrm{CaO}}=\frac{4 \Pi}{3} \times r^{3} \times n \\
& A_{\mathrm{f}-\mathrm{CaO}}=4 \Pi \times r^{2} \times n=\frac{3 V_{\mathrm{f}-\mathrm{CaO}}}{r}
\end{aligned}
$$

Here, $W_{\mathrm{s}}$ is the total weight of the slag $(\mathrm{kg}), \mathrm{W}_{\mathrm{m}}$ is the weight of the hot metal $(60 \mathrm{~kg}), \rho_{\mathrm{s}}$ is the density of the liquid slag $\left.\left(3460 \mathrm{~kg} / \mathrm{m}^{3}\right),{ }^{14}\right) V_{\mathrm{f}-\mathrm{cao}}$ is the volume of $\mathrm{f}-\mathrm{CaO}$ $\left(\mathrm{m}^{3}\right), W_{\mathrm{f}-\text { cao }}$ is the weight of $\mathrm{f}-\mathrm{CaO}(\mathrm{kg}), \rho_{\mathrm{f}-\text { cao }}$ is the density of $\mathrm{f}-\mathrm{CaO}\left(3346 \mathrm{~kg} / \mathrm{m}^{3}\right),{ }^{12,13)} r$ is the radius of $\mathrm{f}-\mathrm{CaO}(\mathrm{m})$,

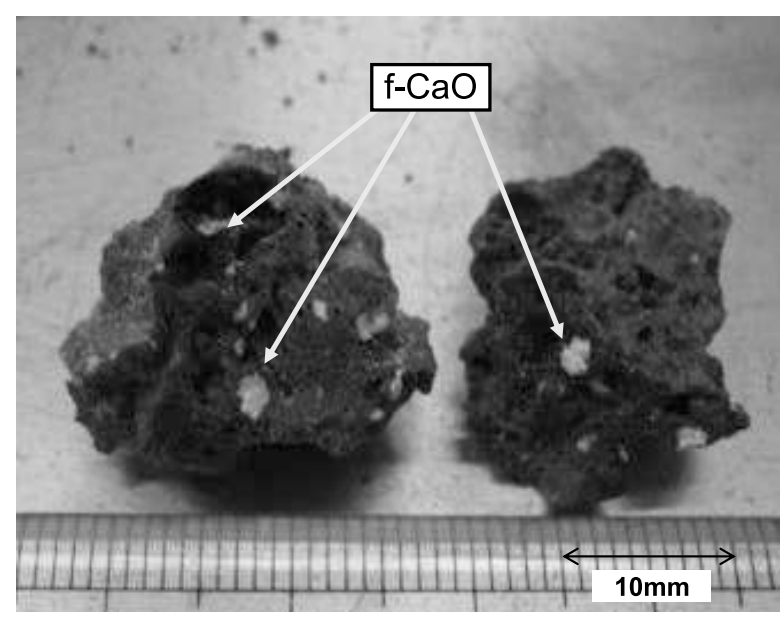

Fig. 14. Photograph of $\mathrm{f}-\mathrm{CaO}$ observed in slag.

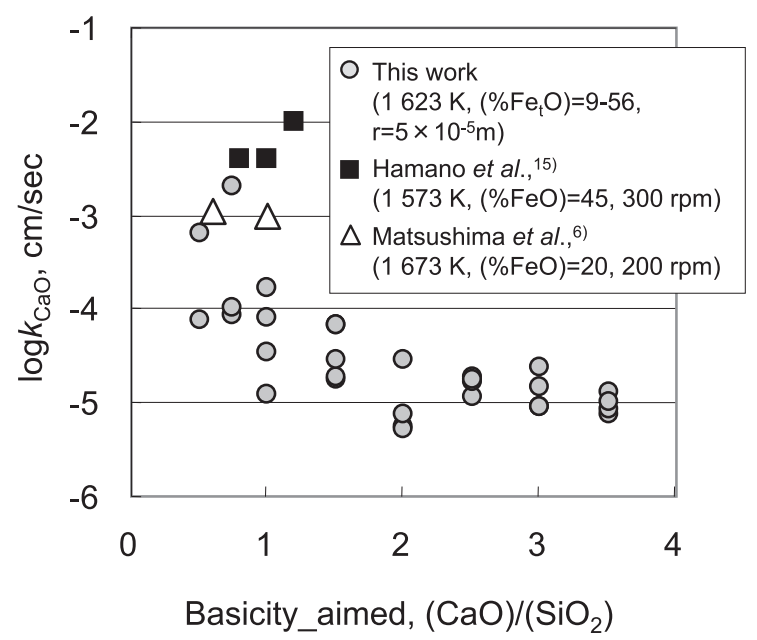

Fig. 15. Mass transfer coefficient of $\mathrm{CaO}$ calculated at each aimed basicity.

and $n$ is the number of free-CaO particles.

An example of a slag sample obtained during the experiment is shown in Fig. 14. The observed $\mathrm{f}-\mathrm{CaO}$ particles in the slag are larger than $0.1 \mathrm{~mm}$, which is the size of the added $\mathrm{CaO}$. This is attributed to aggregation of $\mathrm{CaO}$ particles during the experiments. The size of the aggregated $\mathrm{CaO}$ in the slag is not constant. Therefore, the maximum diameter of the added $\mathrm{CaO}, 0.1 \mathrm{~mm}$ is defined as the $\mathrm{CaO}$ size, and the radius of $\mathrm{CaO}, r=5 \times 10^{-5}(\mathrm{~m})$ is used in the calculations.

The relationship between the aimed slag basicity and $\mathrm{k}_{\text {cao }}$ is shown in Fig. 15. The data reported by Matsushima et al. ${ }^{6)}$ and Hamano et al. ${ }^{15)}$ are also shown in Fig. 15. The $\mathrm{k}_{\text {cao }}$ values obtained in this work are smaller than those in their reports. ${ }^{6,15)}$ In the report by Matsushima et al. ${ }^{6)} \mathrm{k}_{\text {cao }}$ was obtained by the rate of decrease of the radius of a $\mathrm{CaO}$ cylinder submerged and rotated in liquid slag, and the rate of decrease, $\mathrm{dR} / \mathrm{dt}(\mathrm{cm} / \mathrm{s})$ was evaluated by Eq. (16).

$$
\frac{d R}{d t}=\frac{k_{\mathrm{CaO}} \rho_{\mathrm{s}}}{100 \rho_{\mathrm{f}-\mathrm{CaO}}}\{\Delta(\% \mathrm{CaO})\}
$$

Here, $R$ is radius of the $\mathrm{CaO}$ cylinder $(\mathrm{cm})$. In the present work, the slag is located on hot metal stirred by bottomblowing gas, so the stirring condition of the slag is weak compared to that in Matsushima et al. $\left.{ }^{6}\right)$ The obtained $\mathrm{k}_{\text {cao }}$ 
values when the slag basicity is around 1.0 are nearly the same as those reported by Matsushima et al. ${ }^{6}$ ) In this case, $\mathrm{CaO}$ dissolution proceeded to around $100 \%$. Therefore, the obtained data are relatively consistent with the values in the previous reports, even when the added $\mathrm{CaO}$ is completely dissolved. In the case of higher slag basicities of more than $1.5, \mathrm{k}_{\mathrm{cao}}$ tends to decrease with increasing slag basicity, and $\mathrm{k}_{\mathrm{cao}}$ was one order smaller than those in the lower slag basicity region smaller than 1.0.

Since differences in the properties of slag correponding to slag basicity are considered to affect $\mathrm{k}_{\mathrm{cao}}$, the following discussion focuses on the viscosity of slag.

\subsection{Effect of Slag Viscosity on $\mathbf{k}_{\text {cao }}$}

As indicated in 4.1, an equilibrium calculation was conducted based on the obtained slag composition excluding the $\mathrm{f}-\mathrm{CaO}$ and precipitated solid phases at $1623 \mathrm{~K}$. The relationship between the slag viscosity, $\eta_{0}(\mathrm{~Pa} \cdot \mathrm{s})$ at $1623 \mathrm{~K}$ calculated by Factsage and $\mathrm{k}_{\text {cao }}$ categorized by the voluume fraction of the solid phase is shown in Fig. 16. The volume fraction of the solid phase, $\phi(-)$, is defined as shown in Eq. (17).

\section{$\phi=$ \\ $(\% \mathrm{f}-\mathrm{CaO}) / \rho_{\mathrm{f}-\mathrm{CaO}}+(\% 2 \mathrm{CS}) / \rho_{2 \mathrm{CS}}+(\% 2 \mathrm{CS}-3 \mathrm{CP}) / \rho_{2 \mathrm{CS}-3 \mathrm{CP}}$ $(\% \mathrm{f}-\mathrm{CaO}) / \rho_{\text {f-CaO }}+(\% 2 \mathrm{CS}) / \rho_{2 \mathrm{CS}}+(\% 2 \mathrm{CS}-3 \mathrm{CP}) / \rho_{2 \mathrm{CS}-3 \mathrm{CP}}+\left(\%\right.$ slag $\left._{\text {liquid }}\right) / \rho_{s}$}

Here, the contents in Eq. (17) are all weight percent, $\rho_{2 \mathrm{cs}}$ is the density of $2 \mathrm{CS}\left(3300 \mathrm{~kg} / \mathrm{m}^{3}\right),{ }^{12,13)}$ and $\rho_{2 \mathrm{cs}-3 \mathrm{cp}}$ is the density of $2 \mathrm{CS}-3 \mathrm{CP}\left(3195 \mathrm{~kg} / \mathrm{m}^{3}\right){ }^{12,13)}$ As shown in Fig. $16, \mathrm{k}_{\text {cao }}$ decreased slightly with increasing slag viscosity at the same volume fraction. This is attributed to a decreasing diffusion rate of $\mathrm{CaO}$ in slag with increasing slag viscosity. On the other hand, $\mathrm{k}_{\text {cao }}$ is small under the condition of a high volume fraction of solid phase, even when the viscosity of the liquid slag is the same. Therefore, the effect of the solid phase in slag on the slag viscosity will be discussed as follows.

The viscosity of a suspension of a solid and liquid mixture has been widely studied in the field of chemical engineering. ${ }^{16,17)}$ The slag in this work can be assumed as a suspension of a solid and liquid mixture. In the case of dilute suspension (solid ratio $<2 \%$ ), the effect of the solid phase on viscosity can be evaluated by Einstein's equation, shown here as Eq. (18).

$$
\eta_{\mathrm{r}}=\frac{\eta}{\eta_{0}}=1+2.5 \phi
$$

Here, $\eta_{\mathrm{r}}(-)$ is relative viscosity, and $\eta(\mathrm{Pa} \cdot \mathrm{s})$ is the viscosity of the supension.

In this work, the solid fraction is larger than $2 \%$, and in this case, the slag viscosity can be estimated by the Mori and Ototake ${ }^{17)}$ Eq. (19), which was expanded to the higher solid fraction.

$$
\eta_{\mathrm{r}}=\frac{\eta}{\eta_{0}}=1+\frac{d-S_{\mathrm{r}}}{2} \times \frac{1}{1 / \phi-1 / \phi_{\mathrm{vc}}}
$$

Here, $d(\mathrm{~m})$ is the average diameter of the suspended particles, $S_{\mathrm{r}}\left(\mathrm{m}^{2}\right)$ is the specific surface area of the particles in a unit volume, and $\phi_{\mathrm{vc}}(-)$ is the limit volume concentration. If the particle shape is assumed to be spherical, $d \cdot S_{\mathrm{r}} / 2=3$ regardless of the size distribution of the particles. Hence, the relative viscosity is a function only of the solid volume fraction. Moreover, if the cube filling rate of spherical particles of the same size can be defined as the limit volume concentration, $\phi_{\mathrm{vc}}(-)=0.52$. This is the limit concentration in case shearing deformation of the spherical particle layer occurs continuously and steadily. In this work, the viscosiy is calculated assuming that the solid particles are all spherical.

$$
\eta=\eta_{\mathrm{r}} \times \eta_{0}=\eta_{0} \times\left(1+\frac{3}{1 / \phi-1 / 0.52}\right)
$$

The calculated viscosity becomes infinitely large when the solid volume fraction is 0.52 , and viscosity is calculated as a minus value when the solid volume fraction is larger than 0.52 . That is, at solid fractions larger than $52 \%$, it is assumed that the shearing deformation of the spherical particle layer is not realized due to contact between the solid particles, and for this reason, Eq. (20) cannot be applied.

Accordingly, in this work, the viscosity of the solid and liquid phase mixture was evaluated for solid fractions smaller than 52\%. The calculation results are shown in Fig. 17. Equation (18) is used in case $\phi$ is smaller than $2 \%$, and Eq. (20) is used in case $\phi$ is between 2 and $52 \%$. The

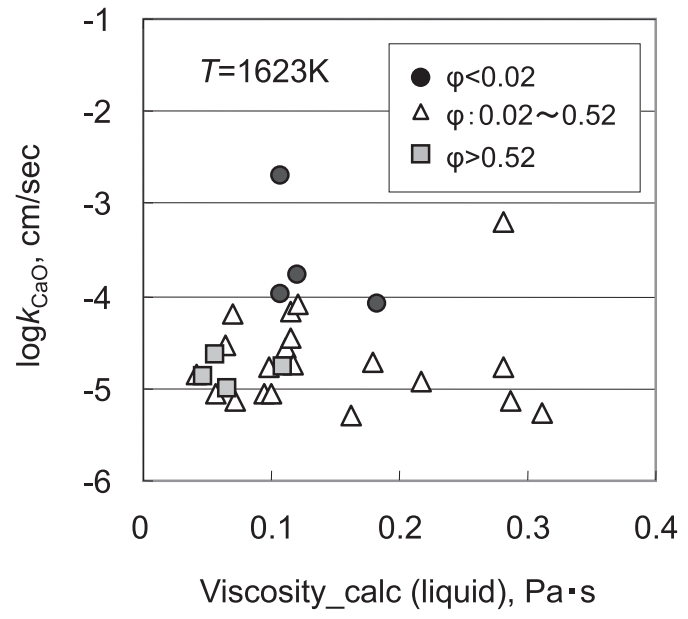

Fig. 16. Influence of slag viscosity (liquid) on mass transfer coefficient of $\mathrm{CaO}$.

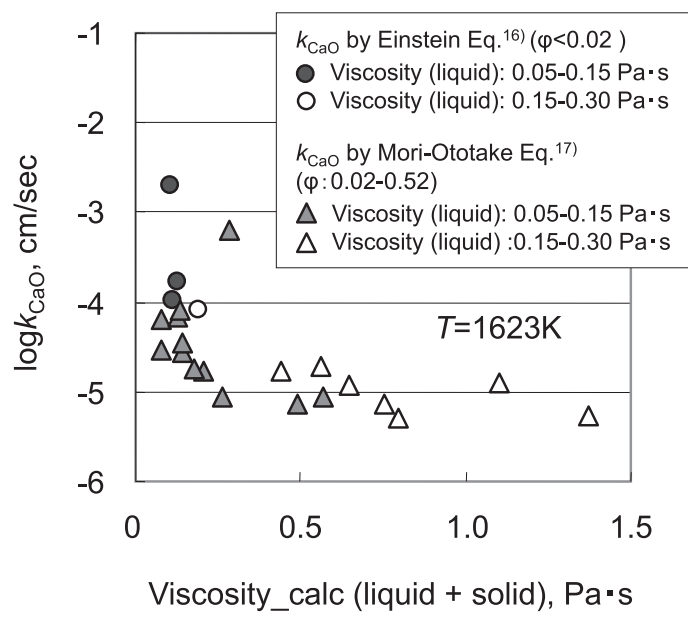

Fig. 17. Influence of slag viscosity (solid-liquid coexistent) on mass transfer coefficient of $\mathrm{CaO}$. 
horizontal axis of Fig. 17 is the mass transfer rate of $\mathrm{CaO}$ in slag calculated by Eq. (9). $\mathrm{k}_{\text {cao }}$ decreased with increasing slag viscosity considering the effect of the solid fraction. $\mathrm{k}_{\text {cao }}$ decreased remarkably under the condition that the slag viscosity was in the range between 0.05 and $0.25 \mathrm{~Pa} \cdot \mathrm{s}$, and shifted to the order of $10^{-5} \mathrm{~cm} / \mathrm{s}$ at slag viscosities higher than $0.25 \mathrm{~Pa} \cdot \mathrm{s}$.

In this work, the $\mathrm{CaO}$ dissolution rate is high, but the hot metal dephosphorization rate is low when the slag basicity is smaller than 1.0. On the other hand, the hot metal dephosphorization rate decreased with increasing $\mathrm{CaO}$ addition at higher slag basicities larger than 1.0. In this case, in addition to a smaller driving force of $\mathrm{CaO}$ dissolution into the liquid slag, $\Delta(\% \mathrm{CaO})$, the slag viscosity also becomes higher overall due to the presence of solid phases such as $\mathrm{f}-\mathrm{CaO}$ and $2 \mathrm{CS}(-3 \mathrm{CP})$, and this higher viscosity prevents both mass transfer of $\mathrm{CaO}$ in the liquid slag and $\mathrm{CaO}$ dissolution. Therefore, under a condition of higher slag basicity, it is important to control the slag composition to the lower $\mathrm{SiO}_{2}$ and higher $\mathrm{FeO}$ region before $\mathrm{CaO}$ addition, and strong stirring is effective for $\mathrm{CaO}$ dissolution. Moreover, the existence of an optimum slag basicity for obtaining higher $\mathrm{CaO}$ efficiency for dephosphorization and increasing the dephosphorization rate was also suggested. Further investigation is needed, including clarification of the oxygen supply by oxygen gas, the change in the melting point by iron oxide addition, and stirring by the decarburization reaction. Futhermore, an investigation of the effect of the size of $\mathrm{CaO}$ on its dissolution rate through larger scale experiments is also necessary.

\section{Conclusion}

The effect of the $\mathrm{CaO}$ dissolution rate on hot metal dephosphorization was investigated in small-scale experiments. The conclusions are as follows,

(1) The dephosphorization rate at $1623 \mathrm{~K}$ showed higher values at basicities of 0.5 to 1.0 . At basicity higher than 1.0, the dephosphorization rate decreased due to poor $\mathrm{CaO}$ dissolution in the flux.

(2) The free $\mathrm{CaO}$ (f-CaO: undissolved $\mathrm{CaO}$ ) content in the slag increased with increasing slag basicity. The saturated $\mathrm{CaO}$ content in slag, $(\% \mathrm{CaO})_{\text {sat., }}$ obtained by a thermodynamic calculation for $2 \mathrm{CaO} \cdot \mathrm{SiO}_{2}\left(-3 \mathrm{CaO} \cdot \mathrm{P}_{2} \mathrm{O}_{5}\right)$ precipitation decreased with increasing slag basicity.

(3) The total reaction rate constant of $\mathrm{CaO}$ dissolution and the mass transfer coefficient of $\mathrm{CaO}$ in slag was calculated from the $\mathrm{f}-\mathrm{CaO}$ content and $(\% \mathrm{CaO})_{\text {sat. }}$ obtained by a thermodynamic calculation. The obtained $\mathrm{k}_{\text {cao }}$ was substantially the same as that in the previous reports at the aimed basicity of around 1.0, which is the condition of a higher liquid fraction.

(4) Higher $\mathrm{k}_{\text {cao }}$ was obtained by a smaller liquid slag viscosity in the case of a lower solid fraction of slag. In the case of a higher solid fraction of slag, $\mathrm{k}_{\text {cao }}$ decreased as the solid fraction increased, even at the same liquid slag viscosity. The stirring energy acting on slag is decreased by the solid fraction. These results suggest the existence of an optimum basicity for higher $\mathrm{CaO}$ efficiency and an increased dephosphorization rate.

\section{Symbols}

$A_{\mathrm{f}-\mathrm{CaO}}:$ Sum of surface area of free-CaO $\left(\mathrm{m}^{2}\right)$

$(\% \mathrm{CaO})$ : Total $\mathrm{CaO}$ content in slag $(\mathrm{wt} \%)$

$(\% \mathrm{CaO})_{\text {liquid }}$ : $\mathrm{CaO}$ content in liquid slag $(\mathrm{wt} \%)$

$(\% \mathrm{CaO})_{2 \mathrm{CS}-3 \mathrm{CP}}: \mathrm{CaO}$ content in $2 \mathrm{CS}-3 \mathrm{CP}(\mathrm{wt} \%)$

$(\% \mathrm{CaO})_{\text {sat. }}$ : Saturated $\mathrm{CaO}$ content in liquid slag (wt $\left.\%\right)$

$\mathrm{C} / \mathrm{S}_{\text {aimed }}$ : Aimed basicity (-)

$d$ : Average diameter of suspended particles (m)

f-CaO: Free $\mathrm{CaO}$ (undissolved $\mathrm{CaO}$ in slag)

(\%f-CaO): Free $\mathrm{CaO}$ content in slag (wt $\%)$

$k_{\mathrm{CaO}}$ : Mass transfer rate $(\mathrm{cm} / \mathrm{s})$

$K_{\mathrm{CaO}}$ : Total reaction rate constant $(1 / \mathrm{min})$

$n$ : Number of free $\mathrm{CaO}$ particles $(\mathrm{N})$

$[\% \mathrm{P}]$ : Phosphorus content in hot metal (wt\%)

$R$ : Radius of $\mathrm{CaO}$ cylinder $(\mathrm{cm})$

$S_{\mathrm{r}}$ : Specific surface area of particles in a unit volume $\left(\mathrm{m}^{2}\right)$

$t$ : Time (min)

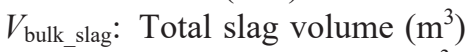

$V_{\mathrm{f}-\mathrm{CaO}}$ : Free $\mathrm{CaO}$ volume $\left(\mathrm{m}^{3}\right)$

$V_{\mathrm{m}}$ : Hot metal volume $\left(\mathrm{m}^{3}\right)$

$W_{\text {f-CaO}}$ : Free $\mathrm{CaO}$ weight $(\mathrm{kg})$

$W_{\mathrm{m}}$ : Hot metal weight $(\mathrm{kg})$

$W_{\mathrm{s}}$ : Slag weight $(\mathrm{kg})$

$\eta$ : Viscosity of suspension $(\mathrm{Pa} \cdot \mathrm{s})$

$\eta_{0}$ : Viscosity of liquid slag $(\mathrm{Pa} \cdot \mathrm{s})$

$\eta_{\mathrm{r}}$ : Relative viscosity (-)

$\rho_{2 \mathrm{CS}}$ : Density of $2 \mathrm{CS}$ phase $\left(\mathrm{kg} / \mathrm{m}^{3}\right)$

$\rho_{2 \mathrm{CS}-3 \mathrm{CP}}$ : Density of 2CS-3CP phase $\left(\mathrm{kg} / \mathrm{m}^{3}\right)$

$\rho_{\mathrm{f}-\mathrm{CaO}}$ : Density of $\mathrm{CaO}\left(\mathrm{kg} / \mathrm{m}^{3}\right)$

$\rho_{\mathrm{s}}$ : Density of liquid slag $\left(\mathrm{kg} / \mathrm{m}^{3}\right)$

$\varphi$ : Volume fraction of solid phase (-)

$\varphi_{\mathrm{vc}}$ : Limit volume concentration (-)

\section{REFERENCES}

1) Y. Ogasawara, A. Matsui, N. Kikuchi, Y. Miki and Y. Kishimoto: CAMP-ISIJ, 25 (2012), 308, CD-ROM (in Japanese).

2) T. Tamura, M. Miyata, Y. Higuchi and T. Matsuo: CAMP-ISIJ, 25 (2012), 204, CD-ROM (in Japanese).

3) M. Ishikawa, T. Matsuo and T. Kawaguchi: Tetsu-to-Hagané, 91 (2005), 528 (in Japanese).

4) A. Tazuke, T. Fujita, T. Abiko and T. Sugitani: CAMP-ISIJ, 25 (2012), 309, CD-ROM (in Japanese).

5) Y. Ogawa, M. Yano, S. Kitamura and H. Hirata: Tetsu-to-Hagané, 87 (2001), 21 (in Japanese).

6) M. Matsushima, S. Yadoomaru, K. Mori and Y. Kawai: Tetsu-toHagané, 62 (1976), 182 (in Japanese).

7) S. Kitamura, K. Miyamoto, H. Shibata, N. Maruoka and M. Matsuo: Tetsu-to-Hagané, 95 (2009), 313 (in Japanese).

8) S. Ohguchi, D. G. C. Robertson, B. Deo, P. Grieveson and J. H. E. Jeffes: Ironmaking Steelmaking, 11 (1984), 202.

9) M. Pajunen and J. Kivilahti: Z. Metallkd., 83 (1992), 17.

10) K. C. Hari Kumar, P. Wollaiits and L. Delaey: Calphad, 18 (1994), 223.

11) W. O. Philbrook and L. D. Kurkbride: J. Met., 8 (1956), 351.

12) S. Hara and K. Ogino: Tetsu-to-Hagané, 76 (1990), 360 (in Japanese).

13) A. Sato, G. Aragane, F. Hirose, R. Nakagawa and S. Yoshimatsu: Tetsu-to-Hagané, 69 (1983), 384 (in Japanese).

14) Y. Kawai, K. Mori, H. Shiraishi and N. Yamada: Tetsu-to-Hagané, 62 (1976), 53 (in Japanese).

15) T. Hamano, M. Horibe and K. Ito: ISIJ Int., 44 (2004), 263.

16) A. Einstein: Ann. Phys., 324 (1906), 289.

17) Y. Mori and N. Ototake: Kagaku Kougaku, 20 (1956), 488 (in Japanese). 